Journal of Engineering and Applied Sciences 15 (6): 1473-1480, 2020

ISSN: 1816-949X

(C) Medwell Journals, 2020

\title{
Family’s Green Brand Purchasing Behavior in Bali
}

\author{
Ni Wayan Ekawati, I Gusti Agung Ketut Suasana and dan Gede Bayu Rahanatha \\ Department of Management, Faculty of Economics and Business, Bukit Jimbaran Campus, \\ Udayana University, Bali, Indonesia
}

\begin{abstract}
The increase in efforts to protect the environment can be achieved by producing eco-friendly products and increasing capability to improve the impression towards eco-friendly product brand (green brand). The availability of eco-friendly products and consumption patterns of green communities are expected to be able to influence their buying behavior. The behavior of purchasing eco-friendly products has started to appear in society which was largely triggered by the behavior of their families. The purpose of this study is to explain the effect of green brand personality and consumer attitudes on green purchasing behavior and how the role of attitude as a mediator influences the relationship of green brand personality to green purchasing behavior. This study was conducted on consumers who use eco-friendly brands in all districts in Bali. The analysis technique used is (structural equation modeling) based on AMOS. Research findings indicate that all variables are positively and significantly related. However, attitude does not act as a mediator for the influence of the green brand personality on green buying behavior. These findings are expected to be used as a consideration by producers and marketers to face further competition and can be used as an alternative strategy to develop eco-friendly businesses. Meanwhile, it is expected to be an input for the government in making policies that encourage the rate of economic growth in Bali.
\end{abstract}

Key words: Attitude, green brand personality and green buying behavior, competition, attitudes, purpose, buying

\section{INTRODUCTION}

Various efforts as well as the involvement of various parties are needed to prevent the pollution of the marine environment. One way is to involve producers that have environmental commitments which means when producing products, these entrepreneurs have a high commitment to strive in protecting the natural environment (Suasana and Ekawati, 2018). The entrepreneurs as the producers are expected to be able to contribute in the efforts to protect the natural environment by attempting to produce products and services that are nature-friendly (Ekawati et al., 2017). An increase in the efforts to protect the environment can be achieved by producing eco-friendly products and increasing the ability to improve the impression towards eco-friendly products (green brand). The availability of eco-friendly products and consumption patterns of people who care about the environment are expected to be able to influence people's buying behavior. The behavior of purchasing eco-friendly products has started to appear in the community which was largely triggered by the behavior of their families. The family provides an important role in understanding purchasing decisions for green products (Salloum et al., 2013).

The decision-making behavior of purchasing green products is influenced by the increase in the level of consumer attention to the natural environment and product attributes (Magnusson et al., 2003). Some main drivers of purchasing decisions on green products, especially, health products are because attributes of green products are beneficial and have no side effects (Aertsens et al., 2011). It is also driven by confidence that the quality of green products is relatively different and very beneficial for health (Chen and Chang, 2012). Another motive that influences the buying behavior of green products is the functional attribute that accompanies green products(Young et al., 2010).

Low quality of green products with poor attributes will affect attitudes that result in a tendency of personal conflict with consumers towards their sense of responsibility to protect the natural and social environment. This situation will create a wider gap in their behavior of purchasing green products (Tsakiridou et al., 2008). Individual attitude and egoism values such as health, safety and hedonic values in using green products can encourage the creation of a family's preferences as consumers (Cerjak et al., 2010). Thus, it appears that the purchasing behavior of green products is due to the moral obligations of the family as consumers and concern for the natural environment as well as the desire to improve family welfare. The family's decision to purchase a green brand will require some consideration

Corresponding Author: Ni Wayan Ekawati, Department of Management, Faculty of Economics and Business, Bukit Jimbaran Campus, Udayana University, Bali, Indonesia 
because it has to meet the needs of all members of the family. Therefore, the behavior will be more selective in the case of green purchasing decisions.

The purchasing behavior of green products needs to be supported by the availability of products with various brands in the community. Green brands of health products in Indonesia have started to develop, along with an increase in demand. Green brands that are quite popular in demand are healthy food products. A brand is a name, term, sign, symbol, design or combination of these that is intended to be recognized as a product or service from a person or seller and to distinguish it from competitor's products. A producer or seller of a product can be identified by their brand. A brand is also a promise of the seller to convey conclusions about nature, benefits and specific services consistently to the buyer (Tan et al., 2012).

Consumer's ties with an eco-friendly brand tend to be better and more impressive rather than with a no personality brand. Brand personality is a set of human characteristics that are related to the brand. Like a human being, a brand can also have a variety of personalities such as being professional or competent (Aaker, 2008). Brand personality is currently an interesting and important topic in marketing research because it helps to distinguish one brand from another. Furthermore, brand personality can build emotional aspects and magnify the personal meaning (personality) of a brand. Brand personality involves the characteristics found in human or consumer personality and also the characteristics of a brand or product that is differentiable and affects consumer behavior (Aaker, 1997). Eco-friendly brands need to pay attention to the uniqueness they offered compared to other brands, e.g., able to provide unique benefits and appearance.

Brand personality plays a very important role in influencing consumer attitudes and consumer behavior which was revealed in many studies (Sirgy, 1982). Green brand personality in an eco-friendly brand will be very helpful in forming a brand image with natural brand characteristics. A good green brand personality will emerge when it can inflict the attitude towards buying decision behavior.

Green products and brands have started to enter the consumer market and consumers have started to switch for eco-friendly products (Shobeiri et al., 2006). Thus, a strong commitment is needed to provide good quality of green products. The characteristics found in a green brand must be the main value offered because the benefits and values can provide an image personally to consumers (Paulraj, 2008). The success of the green brand personality will form a certain attitude. A strong green brand personality is expected to shape the buying behavior of green products attached to consumers. Behavior on green purchasing decisions is expected to be formed from a green brand personality with all the attributes and attitudes shaped in the minds of consumers.

Initial search shows that there is a significant trend towards consumer's needs for natural products (green product), especially, food, beverages and health supplements with various brands (green brand). The increasing need for a natural product from the offered brand indicates that the products and brands are starting to be accepted. A green brand that gets good reception in the community indicates that there is a symptom that can create certain attitudes and certain behaviors for consumers. This symptom requires further identification of its validity as an initial step for the company to determine the next strategy. So, it becomes an important variable for further research, whether or not the symptom can later be an opportunity to develop a green brand personality strategy of health food. Also, this study is motivated by many requests to back to nature as well as to support Bali as a green province. Researches related to the green product are still very few, especially, concerning green brand personality. There is also no research involving green brand personality variables on health products, their influence on attitude and behavior of green product purchasing decisions. Therefore, it is very important and interesting to be investigated further.

\section{Literature review}

Green product: A green product is a product that is designed to minimize environmental impacts during the product life cycle, specifically, minimizing the use of non-renewable resources, avoiding toxic materials and adjusting the use of renewable resources with appropriate level (Albino et al., 2009). The very clear characteristics of the green product are usually it is a nondurable product, made from natural ingredients and using an easily recycled packaging. A green product is a product with positive benefits for consumers and also social benefits that are felt by consumers which is friendly to the natural environment from the production process to consumption (D’Souza et al., 2006). Green product criteria, according to D'Souza et al. (2006) in their research, explained that product perception from the consumer side sees green product or eco-friendly product as a product that is not harmful to animals and the natural environment. Product packaging can present certain elements and appears to be related with environmental concerns. The composition of recycled materials can show the use of materials within certain limits and also firmly show overall use with a lower level or amount as well as minimize the occurrence of damage to the environment.

An eco-friendly product is a product that is designed and processed in a way to reduce the environmental pollution, both in the process of production, distribution and consumption (Ekawati et al., 2016). The community's market actually does not have any kind of nature-friendly 
products that are truly pure as eco-friendly products named as green products. Intensive management to produce eco-friendly products is essentially, all activities strived to protect the natural environment in terms of energy use resources and emissions in the manufacturing process, distribution, utilization, until the final disposal stage. It means, the category of green product is relative and is a description of the products that cause little impact on the environment (Polonsky et al., 1998).

Rath (2013) stated that green products are the result of industrial products produced using eco-friendly technology and caused no harm to the environment. Green product indicators that often used is referring to the opinion by Elkington (1997) including the danger level of product to human health, the packaging inflicted by the product, raw material and ecolabel certificate/eco-friendly product certificate. These indicators are also referenced by other researchers such as Octaviani. Therefore, it can be concluded that a green product is a product that is categorized as environment-friendly or not harmful to the natural environment, both during the production process and consumption.

Green brand: One marketing strategy alternative which can be applied by companies that offer eco-friendly products is using the green brand. Joachimsthaler and Aaker (1999) stated that the identity of a brand is a concept that emerges from the company and becomes the foundation for building a good brand. A brand can be a name, term, symbol, design or combination of the four that identify the seller's products and distinguish them from competing products (Lamb et al., 2001). A brand is a product or service in which the dimensions can distinguish these brands from other products or services that are designed to satisfy the same needs (Kotler and Keller, 2012). Therefore, it can be concluded that the green brand is an identifier, a construction created by the producer in the form of a logo, name, symbol, character and others that can symbolize its commitment to the environment. Green brand as a differentiator in which a brand that can distinguish similar other products and services for differences in commitment to environmental preservation (Hartmann et al., 2005; Lamb et al., 2001; Kotler and Keller, 2012).

Brand personality: Brand personality is a set of human characteristics that are linked to or associated with a brand (Aaker, 1997). Brand personality as a mixture of certain human traits that can be connected with a certain brand. Same as these two definitions, Louis and Lombart (2010) define brand personality as the whole personality trait used to characterize a person and have an association with a brand. The idea that inanimate objects such as brands can be related to a set of human characteristics is well accepted by social psychologists. The basic argument is that attitudinal targets such as brands can be linked to personality traits that provide expressive or symbolic benefits for consumers. Self-expression can be a driver that influences consumer preferences and choices (Aaker, 1997). Brand personality is formed through the consumer perception of a particular brand. Consumer perception will be stored in each individual (Kapferer, 2008). In other words, the personality of a brand is in the mind or perception of consumers that are formed directly or indirectly through direct experience in using products or through marketing efforts. Brand personality is formed through brand name, symbol or logo, advertisements, product attributes and spokesperson (Grohmann, 2009).

Brand personality is a framework that describes and measures brand personality which is analogous to human personality can be seen in five dimensions (Aaker, 1997) which are sincerity. This dimension shows a sincere human nature which is reflected by down-to-earth nature, family-oriented, honest, realistic, wholesome, cheerful, sentimental and friendly. Sincerity reflects how a brand is really capable to show consistency in meeting the needs, desires and expectations of consumers. Excitement is how a brand capable to give joy or pleasure to the user. This is reflected like contemporary, independent, up-to-date, unique, imaginative, young, cool, spirited, exciting, trendy and daring. This dimension is more indicative of a product or brand capable of providing pleasure and pride) Competence. This dimension is shown by the characteristics such as being reliable, hardworking, intelligent, technical, successful, leadership spirit and confident. Skills show that a brand can show its existence or presence in the market and the ability to compete. Sophistication is a dimension that can appear to have characteristics such as upper-class, glamorous, goodlooking, charming, feminine and smooth. The dimension of sophistication refers more to how a brand provides value to its users. Ruggedness is shown by the nature of individuals who like challenges (outdoorsy), tend to be masculine, tough and rugged. This dimension shows how a brand can survive amid competition with other brands.

Attitude: The attitude in general is an individual or consumer feeling that arises in response to an object. The attitude formed in the minds of consumers becomes an important factor that influences subsequent consumer decisions. The consumer attitude formation appears to have a relationship between previous beliefs, attitudes and behaviors. The belief, attitude and behavior formed are closely related to what is stored in the mind of consumers, especially, related to product attributes. Product attribute that is a characteristic of a product will strongly influence consumer attitude. Consumers are more likely to carry out certain positive behavior if they have a positive attitude towards carrying out the behavior (Kim and Chung, 2011).

Attitude contains three components, namely the cognitive component (the perceptual component) which is a component related to knowledge, view of belief, related to how people's perceptions of the attitude object. 
This is a representation of what is believed by the individual owner of attitude. Often the cognitive component is equated with the view (opinion) when it involves issues or controversial issues. Affective component (emotional component) which is a component related to feeling happy or displease towards the attitude object. Joy is a positive thing while displeasure is a negative thing. This component shows the direction of attitude which is positive and negative. This is an individual's feelings toward attitude object and concerning emotional problems. This emotional aspect which is usually rooted deeply as a component of attitude and is the most enduring aspect of the influence that might change someone's attitude. The affection component is equated with the feeling that is held for something. Conative component (the behavioral component) or action component is a component related to the tendency to act on the attitude object. This component shows the intensity of the attitude which shows the size of the tendency to act or behave towards the attitude object. It is an aspect of the tendency to behave following one's attitude. It contains a tendency to act or react to something in certain ways and related to the object at hand. It is logical to expect that a person's attitude is reflected in the form of behavioral tendencies towards an object (Schiffman and Kanuk, 2009).

Attitude can be measured quantitatively and the direction of the relationship of attitude to behavior has four possibilities which are attitude causes behavior, behavior causes attitude, attitude and behavior are reciprocal and attitude and behavior are not interconnected (Wright and Klyn,1998). The statement has received support from several researchers who stated that attitude is an individual predictor of behavior. Attitude is positively correlated to consumer behavior in the environment including eco-friendly products.

Even so, there are opinions that reveal attitude does not affect the behavior formed. This is due to several reasons such as the unclear concept of attitude that is not integrated, generally, unclear between attitude and behavior measurement, no clear specification of attitude and behavior, consideration of the out-of-control behavior (Mondejar-Jimenez et al., 2011). Looking at some of these differences of opinion, it is interesting to see further the role of attitude towards purchasing behavior towards eco-friendly products that occur in Bali as a developing province in the country.

Green purchase behavior: Behavior intention is an action taken by consumers after considering the information and belief obtained. When a belief in an object such as a product attribute has been formed, the belief connects behavior (Ajzen, 1991). Purchase intention becomes a measurement of the likelihood of consumers buying certain products where with higher purchase intentions, the likelihood of purchases will be greater (Schiffman and Kanuk, 2009). Buying behavior is also defined as the activities of individuals who are directly involved in the process of obtaining and using goods or services including the decision-making process in the preparation and determination of these activities (Blackwell et al., 2006).

It is very important for companies that produce eco-friendly products or services to find out consumer's willingness to buy their products even though the price is more expensive than ordinary products (Thieme et al., 2015). Consumers are now willing to pay more for eco-friendly products and are more interested in buying them (Okada and Mais, 2010; Trivedi et al., 2015).

Consumer's desire to buy green products (green purchase intention) is influenced by several factors such as personal norms, subjective norms, attitude, perceived behavioral control and perception (Nam et al., 2017; Khare, 2015). Purchasing behavior towards green products is the tendency of consumers to buy eco-friendly products that are influenced by attitude, personal norms and willingness to pay. These findings can refer to the possibility of being a long-term behavior of consumers towards the need for organic food to reduce the environmental impact that occurs.

Consumer decision making is an integration process that combines knowledge to evaluate two or more alternative behaviors and choose one of them. The result of this integration process is a choice presented cognitively as a desire to behave.

\section{MATERIALS AND METHODS}

This study used a quantitative research design (Creswell, 2010). Quantitative analysis based on multivariate analysis using structural equation modeling or SEM based on AMOS 7.0. The location of the research was carried out in Bali in the community that has consumed herbal branded natural health products (green brand). The consideration of choosing Bali as a research location is based on several factors which are Bali as one of the communities who has a need for herbal-based health products and using herbal-based product brands, nowadays, various eco-friendly brands of herbal products have emerged in Bali, the industry of eco-friendly products that use eco-friendly processes with the resulting brand can support the concept of the company to implement a green approach that at the same time supports the implementation of clean and green applied by the province of Bali. The population of this research is all Balinese who have used eco-friendly products, especially, health products. This population is spread across all regencies in Bali with eight regencies including one municipal city. Sampling used a purposive random sampling technique in which not all populations have the same opportunity as respondents and must meet the criteria needed in this study. 


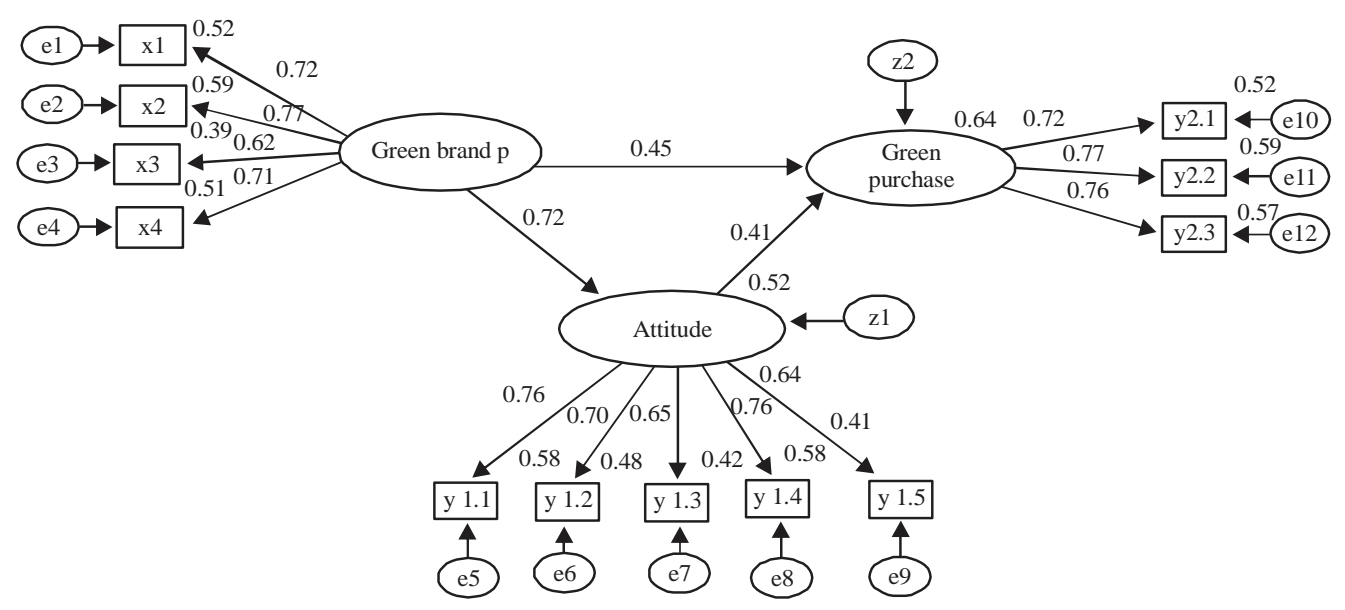

Fig. 1: Effect of green brand personality on green purchase mediated by attitude model

Table 1: The goodness of fit indexes model table

\begin{tabular}{llll}
\hline Goodness of fit index & Cut of value & Model result & Description \\
\hline $\begin{array}{l}\text { Probability }(\mathrm{P}) \\
\chi^{2} \text {-Chi-square }\end{array}$ & $\geq 0.05$ & 0.302 & Good \\
& $<79.08$ & & \\
CMIN/df & $(\mathrm{df}=51, \alpha=0.05)$ & 55.705 & Good \\
GFI & $\leq 2.00$ & 1.092 & Good \\
TLI & $\geq 0.90$ & 0.924 & Good \\
CFI & $\geq 0.95$ & 0.989 & Good \\
RMSEA & $\geq 0.95$ & 0.992 & Good \\
AGFI & $\leq 0.08$ & 0.028 & Good \\
\hline
\end{tabular}

\section{RESULTS AND DISCUSSION}

When each indicator can be accepted and used to define latent variables (construct) based on the estimation results of the measurement model performed by the confirmatory factor analysis technique, the estimation is continued on the structural equation model estimation with the full model analysis technique. This estimation is intended to see the suitability of the model and the causality relationship that occur in a tiered relationship. The estimation results of the structural equation model are shown in Fig. 1. The results of the goodness of fit model of the effect of green brand personality on green purchase mediated by attitude are presented in Table 1 .

Table 1 shows that all goodness of fit index criteria are good and indicated by the $\chi^{2}$ (Chi-square) value of 55.705 and probability $>0.05$ with 0,302 , GFI index with a value of 0.924 is good and the AGFI index with a value of 0.884 is within the marginal criteria. Further, the CMIN/DF index with a value of 1.092, TLI with a value of 0.989 , CFI with a value of 0.992 and RMSEA with a value of 0.028 , all are in good criteria. TLI and CFI indexes are highly recommended to use because these indexes are relatively insensitive to the sample size and are less influenced by the complexity of the model (Ferdinand, 2002), therefore, this model meets the standard of goodness of fit seen from the TLI (Tucker Lewis Index) and CFI (Comparative Fit Index) values.
Estimated results of regressions weights: The estimation results of the regressions weights model of the effect of green brand personality on green purchase mediated by attitude are presented in Table 2 .

Based on the estimation results of standardized regression weights in Table 2 it can be seen that the path coefficient of the effect of green brand personality $\left(\mathrm{X}_{1}\right)$ on attitude $\left(\mathrm{Y}_{1}\right)$ is 0.723 with a significance level of 0.000 . This shows that there is a significant effect between the green brand personality on attitude. Thegreen brand personality $\left(\mathrm{X}_{1}\right)$ variable also has a significant effect on green purchase $\left(\mathrm{Y}_{2}\right)$ with a path coefficient of 0.446 with a significance level of 0.005 . A variable of attitude $\left(Y_{1}\right)$ has a significant effect on green purchase $\left(Y_{2}\right)$ with a path coefficient of 0.414 and a significance value of 0.009 .

Analysis of direct effect, indirect effect and the total effect: Analysis of direct effect, indirect effect and the total effect of the variables studied is intended to determine the strength of the influence between constructs, all three of the direct, indirect and total effect. The results of the AMOS program analysis on the direct effect, indirect effect and the total effect of each variable studied as presented in Table 3.

The effect of green brand personality on attitude: Hypothesis testing of this study produced a value of path coefficient (standardized direct effect) of 0.723 . Furthermore, the p-value obtained in the relationship between the green brand personality $\left(\mathrm{X}_{1}\right)$ and attitude $\left(\mathrm{Y}_{1}\right)$ variables is 0.000 . This can be interpreted that the green brand personality has a positive and significant effect on attitude. The stronger the green brand personality stored in the minds of the public or consumers towards brands of eco-friendly products, the stronger their attitude to support 
J. Eng. Applied Sci., 15 (6): 1473-1480, 2020

Table 2: Estimation of regression weights model of the effect of green brand personality on green purchase mediated by attitude

\begin{tabular}{lllccccc}
\hline Types of effect & & & Estimate standardize & SE & Estimate standardize & CR & p-values \\
\hline Attitude & $<---$ & Green brand personality & 0.709 & 0.139 & 0.723 & 5.113 & 0.000 \\
Green purchase & $<---$ & Green brand personality & 0.522 & 0.187 & 0.446 & 2.785 & 0.005 \\
Green purchase & $<---$ & Attitude & 0.495 & 0.188 & 0.414 & 2.626 & 0.009 \\
\hline
\end{tabular}

Table 3: Direct effect, indirect effect and total effect of the effect of green brand personality on green purchase mediated by attitude model

\begin{tabular}{llr} 
Types of effect & Construct & Standardized estimates \\
\hline Direct effect & Green brand personality->Attitude & 0.723 \\
& Attitude -> green purchase & 0.414 \\
& Green brand personality->Green purchase & 0.446 \\
Indirect effect & Green brand personality->Green purchase & 0.299 \\
Total effect & Green brand personality->Green purchase & 0.745 \\
\hline
\end{tabular}

the attempts to protect the environment. The situation can encourage a stronger attitude toward consuming eco-friendly brands.

The findings of this study are very much in line with the expectation. People should join in efforts to protect the natural environment (Ewert and Baker, 2001; McEwen, 2013). Society as individuals are more aware of the natural environment, aware of the importance of healthy living, so that, awareness emerges of the need for natural products which can encourage them to become consumers who have a caring attitude for the environment (Kim and Chung, 2011).The findings of this study are in accordance with the opinion that green brand personality plays a very important role in influencing consumer attitudes and consumer behavior (Sirgy, 1982). Green brand personality in an eco-friendly product brand will be very helpful in forming a brand image with natural product characteristics. A good green brand personality will emerge as a result of the relevant brand being able to also create a good viewpoint or perception (green brand image).

The effect of attitude on green purchase: The value of the path coefficient (standardized direct effect) obtained from the influence of attitude towards green purchase of 0.414. furthermore, the p-value obtained on the relationship of attitude $\left(\mathrm{Y}_{1}\right)$ variable on green purchase $\left(\mathrm{Y}_{2}\right)$ is 0.000 . This can be interpreted that attitude has a positive and significant effect on the green purchase. The stronger the attitude of the community with their belief in eco-friendly products, the greater their efforts to make purchases of eco-friendly brand products. The green purchase referred here is an effort to purchase by the community towards brands of eco-friendly products, especially, health products circulating in the market.

The findings of this study are in accordance with the statement by Carette et al. (2012) which found that the attitude formed in individuals is very influential on buying behavior towards eco-friendly brands. Attitude as a strong predictor to create a buying behavior of eco-friendly products. The attitude towards the environment is as a mindset to respond to the problem of environmental damage that occurs (Kaiser et al., 1999). A positive mindset can certainly encourage behavior in meeting the needs of life by also attempting to protect the environment. Thus, it is hoped that the behavior of purchasing eco-friendly brands will be increasingly encouraged.

The effect of green brand personality on green purchase: The path coefficient (standardized direct effect) obtained from the influence of green brand personality on green purchase is 0.446 . The p-value obtained in the relationship between the green brand personality $(\mathrm{X})$ variable and green brand personality $\left(\mathrm{Y}_{2}\right)$ is 0.005. This can be interpreted that the green brand personality has a positive and significant effect on the green purchase. The stronger the green brand personalitythat the community has on eco-friendly brands, the greater the community's effort to buy eco-friendly brand products.

Green purchase behavior as a complex form of ethical decision-making behavior and is considered a type of behavior with high social responsibility. The complex behavior is formed from the minds of individuals personally towards eco-friendly products or brands. Green brand personality will unconsciously be formed and attached to individuals with environmental awareness. Thus, it will trigger the power to behave in purchasing green products or brands.

The role of attitude in mediating the relationship between green brand personality and green purchase: The direct effect of green brand personality on green purchase is 0.446 , more than the indirect effect of the relationship between green brand personality onthe green purchase that is 0.299. This means that a green brand personalityhas a direct effect on the green purchase without going through attitude. The stronger the green brand personality, the greater the opportunity of buying behavior of eco-friendly brands. Wherein in this situation, people's buying behavior of eco-friendly brands is not influenced by the presence of a positive attitude from the community. So, without the encouragement of a positive attitude towards the eco-friendly brands, the green brand personality will be able to achieve success in realizing consumer buying behavior. 
Based on these findings, it is really necessary to maintain the strength of green brand personality towards eco-friendly brands, always able to encourage the creation of buying behavior. Likewise, a caring attitude towards a good environment greatly encourages the emergence of green buying behavior. Thus, it is important for eco-friendly brands, especially, for health product brands while maintaining a green brand personality and consumer attitude that care about environmental preservation.

\section{CONCLUSION}

Some conclusions of this study findings are green brand personality has a positive and significant effect on people's attitudes. It means, the stronger the green brand personality or the stronger the people's perception of the personal brand of eco-friendly products, the stronger the drive for a positive attitude associated with understanding the eco-friendly brand. Attitude affects purchasing behavior which can be interpreted that the influence of attitude towards buying behavior is unidirectional. This means that the stronger the positive attitude of the community on eco-friendly brands, the greater the attitude can influence their buying behavior. Green brand personality influences purchasing behavior which states that the stronger the community's perception of personal eco-friendly products brands, the stronger the intention to purchase eco-friendly product brands. Public attitudes on eco-friendly brands do not mediate positively and significantly the effect of green brand personality on buying behavior that occurs. It means that the stronger the green brand personality formed, the stronger the community's attitude towards eco-friendly product brand. This means that the attitude in this study does not have a role as a mediating variable.

\section{REFERENCES}

Aaker, D.A., 2008. Managing Brand Equity: Capitalizing on the Value of a Brand Name. Free Press, New York, USA.,.

Aaker, J.L., 1997. Dimensions of brand personality. J. Market. Res., 34: 347-356.

Aertsens, J., K. Mondelaers, W. Verbeke, J. Buysse and G. van Huylenbroeck, 2011. The influence of subjective and objective knowledge on attitude, motivations and consumption of organic food. Br. Food J., 113: 1353-1378.

Ajzen, I., 1991. The theory of planned behavior. Organiz. Behav. Hum. Decis. Process., 50: 179-211.

Albino, V., A. Balice and R.M. Dangelico, 2009. Environmental strategies and green product development: An overview on sustainability-driven companies. Bus. Strategy Environ., 18: 83-96.
Blackwell, R.D., P.W. Miniard and F.J. Engel, 2006. Consumer Behaviour. 10th Edn., Thomson South-Western, Mason, Ohio, USA., ISBN: 9780324271973, Pages: 774.

Carette, C., M. Malotaux, M.V. Leeuwen and M. Tolkamp, 2012. Shea nut and butter in Ghana: Opportunities and constraints for local processing. Master Thesis, Wageningen University, Wageningen, Netherlands.

Cerjak, M., Z. Mesic, M. Kopic, D. Kovacic and J. Markovina, 2010. What motivates consumers to buy organic food: Comparison of Croatia, Bosnia Herzegovina and Slovenia. J. Food Prod. Marketing, 16: 278-292.

Chen, Y.S. and C.H. Chang, 2012. Enhance green purchase intentions: The roles of green perceived value, green perceived risk and green trust. Manage. Decis., 50: 502-520.

Creswell, J.W., 2010. [Research Design: Approach Qualitative, Quantitative and Mixed]. Pustaka Pelajar, Yogyakarta, Indonesia (In Indonesian),.

D'Souza, C., M. Taghian, P. Lamb and R. Peretiatkos, 2006. Green products and corporate strategy: An empirical investigation. Soc. Bus. Rev., 1: 144-157.

Ekawati, N.W., I.K. Rahyuda, N.N.K. Yasa and I.P.G. Sukaatmadja, 2016. The implmentation of ecopreneurship and green innovation in building competitive advantage to generate success of New Spa products in Bali. Int. Bus. Manag., 10: 2660-2669.

Ekawati, N.W., N.N. Kertiyasa, G.A.K. Giantari and N.K. Sariyathi, 2017. Ecopreneurship and green innovation for the success of New Spa products. J. Bus. Retail Manage. Res., 11: 13-24.

Elkington, J., 1997. Cannibals with Forks: The Triple Bottom Line of 21st Century Business. New Society Publishers, Gabriola Island, Canada.

Ewert, A. and D. Baker, 2001. Standing for where you sit: An exploratory analysis of the relationship between academic major and environment beliefs. Environ. Behav., 33: 687-707.

Grohmann, B., 2009. Gender dimensions of brand personality. J. Market. Res., 46: 105-119.

Hartmann, P., V.A. Ibanez and F.J.F. Sainz, 2005. Green branding effects on attitude: Functional versus emotional positioning strategies. Marketing Intell. Plann., 23: 9-29.

Joachimsthaler, E. and D.A. Aaker, 1997. Building brands without mass media. Harvard Bus. Rev., 75: 39-48.

Kaiser, F.G., M. Ranney, T. Hartig and P.A. Bowler, 1999. Ecological behavior, environmental attitude and feelings of responsibility for the environment. Eur. Psychol., 4: 59-74. 
Kapferer, J.N., 2008. The New Strategic Brand Management: Creating and Sustaining Brand Equity Long Term. Kogan Page, London, ISBN-13: 9780749450854, Pages: 560.

Khare, A., 2015. Antecedents to green buying behaviour: A study on consumers in an emerging economy. Marketing Intell. Plann., 33: 309-329.

Kim, H.Y. and J.E. Chung, 2011. Consumer purchase intention for organic personal care products. J. Consum. Market., 28: 40-47.

Kotler, P.T. and K.L. Keller, 2012. Marketing Management. 14th Edn., Pearson, New Jersey.

Lamb, Hair and McDaniel, 2001. Marketing: Book 1. PT Salemba Empat, Jakarta, Indonesia,.

Louis, D. and C. Lombart, 2010. Impact of brand personality on three major relational consequences (trust, attachment and commitment to the brand). J. Prod. Brand Manage., 19: 114-130.

Magnusson, M.K., A. Arvola, U.K.K. Hursti, L. Aberg and P.O. Sjoden, 2003. Choice of organic foods is related to perceived consequences for human health and to environmentally friendly behaviour. Appetite, 40: 109-117.

McEwen, T., 2013. Ecopreneurship as a solution to environmental problems: Implications for college level entrepreneurship education. Int. J. Acad. Res. Bus. Social Sci., 3: 264-288.

Mondejar-Jimenez, J.A., M. Cordente-Rodriguez, M.L. Meseguer-Santamaria and J.C. Gazquez-Abad, 2011. Environmental behavior and water saving in spanish housing. Int. J. Environ. Res., 5: 1-10.

Nam, C., H. Dong and Y.A. Lee, 2017. Factors influencing consumer's purchase intention of green sportswear. Fashion Textiles, Vol. 4, No. 2. 10.1186/s40691-017-0091-3

Okada, E.M. and E.L. Mais, 2010. Framing the green alternative for environmentally conscious consumers. Sustainability Accounting Manage. Policy J., 1: 222-234.

Paulraj, A., 2009. Environmental motivations: A classification scheme and its impact on environmental strategies and practices. Bus. Strategy Environ., 18: 453-468.

Polonsky, M.J., P.J. Rosenberger III and J. Ottman, 1998. Developing green products: Learning from stakeholders. Asia Pac. J. Marketing Logist., 10: 22-43.
Rath, R.C., 2013. An impact of green marketing on practices of supply chain management in Asia: Emerging economic opportunities and challenges. Int. J. Supply Chain Manage., 2: 78-86.

Salloum, C.C., N.M. Azoury and T.M. Azzi, 2013. Board of director's effects on financial distress evidence of family owned businesses in Lebanon. Int. Entrepreneurship Manage. J., 9: 59-75.

Schiffman, L. and L. Kanuk, 2009. Consumer Behavior. 10th Edn., Pearson Prentice Hall, Upper Saddle River, New Jersey, USA., ISBN-13: 978-0135053010, Pages: 600.

Shobeiri, S.M., B. Omidvar and N.N. Prahallada, 2006. Influence of gender and type of school on environmental attitude of teachers in Iran and India. Int. J. Environ. Sci. Technol., 3: 351-357.

Sirgy, M.J., 1982. Self-concept in consumer behavior: A critical review. J. Consumer Res., 9: 287-300.

Suasana, I.G.A.K.G. and N.W. Ekawati, 2018. Environmental commitment and green innovation reaching success new products of creative industry in Bali. J. Bus. Retail Manage. Res., 12: 246-250.

Tan, T.M., T.W. Liew, L.S.S. William, O.B.F. Michelle and S.M. Tan, 2012. Consumer-based brand equity in the service shop. Int. J. Marketing Stud., 4: 60-77.

Thieme, J., M.B. Royne, S. Jha, M. Levy and W.B. McEntee, 2015. Factors affecting the relationship between environmental concern and behaviors. Marketing Intell. Plann., 33: 675-690.

Trivedi, R.H., J.D. Patel and J.R. Savalia, 2015. Pro-environmental behaviour, locus of control and willingness to pay for environmental friendly products. Market. Intell. Plann., 33: 67-89.

Tsakiridou, E., C. Boutsouki, Y. Zotos and K. Mattas, 2008. Attitudes and behaviour towards organic products: An exploratory study. Int. J. Retail Distrib. Manage., 36: 158-175.

Wright, M. and B. Klyn, 1998. Environmental attitude-behaviour correlations in 21 countries. J. Empirical Generalisations Marketing Sci., 3: 42-60.

Young, W., K. Hwang, S. McDonald and C.J. Oates, 2010. Sustainable consumption: Green consumer behaviour when purchasing products. Sustainable Dev., 18: 20-31. 